\title{
KATEGORI PERTANYAAN BERPIKIR SPASIAL DI DALAM BUKU TEKS GEOGRAFI SMA KELAS XII TERBITAN ERLANGGA
}

\author{
Tivani Monic Sandria ${ }^{1}$, Ahyuni $^{2}$ \\ Program Studi Pendidikan Geografi \\ Fakultas Ilmu Sosial, Universitas Negeri Padang \\ Email tivanimonic@gmail.com
}

\begin{abstract}
Abstrak
Artikel ini dibuat untuk menganalisis dan mengkategorikan pertanyaan berpikir spasial yang dimuat di dalam buku teks geografi kelas XII terbitan Erlangga yang digunakan di SMAN 3, SMAN 6, dan SMAN 8 Padang. Penelitian ini menggunakan metode kuantitatif dengan pendekatan analisis konten/isi. Sumber data penelitian adalah buku teks buku teks terbitan Erlangga karangan K. Wardiyatmoko kelas XII. Analisis data dilakukan dengan teknik persentase. Hasil penelitian menunjukkan bahwa jumlah total pertanyaan adalah 370 butir, yang dikategorikan berdasarkan letak pertanyaan, yaitu di awal bab, tengah bab, dan akhir bab. Kategori nonspasial termuat di dalam 200 pertanyaan dengan persentase 54,05\%, 56 termasuk ke dalam kategori spasial primitif dengan persentase $15,14 \%$. Sebanyak 78 pertanyaan termasuk kategori spasial sederhana dengan persentase $21,08 \%$, dan 36 pertanyaan termasuk ke dalam kategori kompleks spasial dengan persentase 9,73\%. Jadi, dapat disimpulkan bahwa buku teks geografi kelas XII tersebut didominasi oleh pertanyaan kategori nonspasial.
\end{abstract}

Kata kunci: Berpikir Spasial, Buku Teks, Erlangga

Abstract

This article was written to analyze the spatial thinking categories included in Erlangga geography textbooks class XII that currently used in SMAN 3, SMAN 6, and SMAN 8 Padang. This research used quantitative method with content analyze approach. The data sources of this research is Erlangga geography textbooks class XII, written by $K$. Wardiyatmoko. The data analyze used percentage technique. The results shows that the total amount of questions in geography textbook are370, categorized by question location, which is at the beginning of the chapter, inside the text, and the end of the chapter. The amount of nonspatial questions are 200 with percentage 54,05\%, 56 are primitive spatial with percentage 15,14\%, 78 are simple spatial with percentage 21,08\%, and 36 questions are complex spatial with percentage 9,73\%. So, the conclusion is that Erlangga geography textbook class XII was dominated by nonspatial category.

Keywords: Spatial Thinking, Textbook, Erlangga

\footnotetext{
${ }^{1}$ Mahasiswa Program Studi Pendidikan Geografi

${ }^{2}$ Dosen Jurusan Geografi Fakultas Ilmu Sosial Universitas Negeri Padang
} 


\section{PENDAHULUAN}

Kemampuan berpikir spasial merupakan salah satu contoh dari kemampuan berpikir lainnya, seperti: verbal, logical, statistical, hipetetical, dan lain-lain. National Research Council mengartikan proses berpikir spasial sebagai pemikiran yang universal, salah satu yang dapat diakses oleh semua orang dalam konteks yang berbeda.

Jo (2007) menguraikan kemampuan berpikir spasial terdiri dari tiga unsur, yaitu ruang (space), alat (tools), dan proses pemikiran atau pertimbangan penalaran (process of reasoning). Unsur tersebut dapat dijadikan sebagai alat untuk menyusun masalah, menemukan jawaban, dan mengkomunikasikan solusinya dengan mengekspresikan hubungan dalam struktur keruangan seperti peta.Sehingga kita dapat mempersepsi, mengingat, dan menganalisis sifat-sifat statis dan dinamis objek dan hubungannya dengan objek itu sendiri.

Di dalam buku Learning to Think Spatially(Downs: 2006)dijelaskan bahwa ada tiga konteks dalam berpikir spasial. Pertama, life space atau pengetahuan dalam ruang, yaitu berpikir tentang bumi yang kita tempati saat ini, termasuk di dalamnya tentang menemukan jalan dan navigasi, maupun aktivitas sehari-hari seperti: mengikuti petunjuk arah di jalanan. Kedua, physical space atau pengetahuan mengenai ruang.cKonteks ini lebih fokus kepada pemahaman saintifik mengenai alam, struktur, dan kegunaan dari fenomenafenomena yang terjadi. Mulai dari skala yang paling kecil (mikroskopik) hingga yang paling besar (astronomikal), seperti penjelasan mengenai DNA manusia hingga pergerakan tata surya.Ketiga adalah intellectual space atau pengetahuan dengan ruang.Objek yang diinvestigasi dengan konteks ketiga ini termasuk spasial apabila ada koordinasi antara waktu dan ruang, contohnya: penulisan simbol.

Geografi merupakan subjek yang paling tepat untuk menggunakan kemampuan berpikir spasial.Karena pada dasarnya geografi juga membahas tentang ruang.Seperti yang dijelaskan Ahyuni (2016) bahwa berpikir spasial merupakan kekhasan bidang ilmu geografi dimana seseorang harus mengintegrasikan pengetahuan tentang konsep spasial, kemampuan menggunakan representasi spasial dalam cara yang efektif, serta keterampilan penalaran spasial untuk memecahkan masalah dan mengambil keputusan.

Berpikir spasial merupakan sebuah bentuk berpikir yang kompleks (Ahyuni, 2016).Jo dan Bednarz merumuskan kemampuan berpikir spasial seperti gambar berikut.

Gambar 1. Taksonomi Berpikir Spasial Menurut Jo-Bednarz.

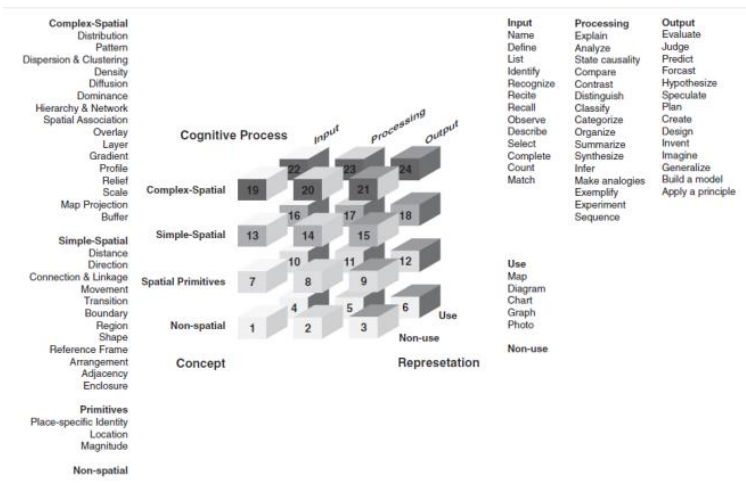

Sumber: Evaluating Geography Textbook Question From a Spatial Perspective: Using Concepts of Space, Tools of Representation, and Cognitive Processes to Evaluate Spatiality (Bednarz dan Jo, 2014). 
Sebelumnya, penelitian mengenai berpikir spasial sudah pernah dilakukan.Salah satunya adalah penelitian Irma Lutfianingsih (2017) mengenai perbandingan kemampuan berpikir spasial kelas XII IPA dengan XII IPS di SMAN 10 Yogyakarta.Hasil penelitian tersebut menunjukkan bahwa kemampuan berpikir spasial siswa kelas XII IPS lebih tinggi daripada kelas XII IPA.

Di dalam proses belajar mengajar, buku teks digunakan untuk mendukung proses pembelajaran. Penelitian mengenai aspekaspek berpikir spasial di dalam buku teks geografi sudah pernah dilakukan di Amerika Serikat oleh Injeong Jo pada tahun 2007. Dari hasil penelitian tersebut, dapat disimpulkan bahwa buku teks geografi yang digunakan di Amerika Serikat masih belum mendukung kemampuan berpikir spasial siswa, yang dibuktikan dengan banyaknya pertanyaan-pertanyaan dengan konsep level rendah dibandingkan konsep level tinggi. Berdasarkan asumsi penulis, buku-buku teks geografi di Indonesia juga belum menerapkan aspek-aspek berpikir spasial di dalam pertanyaan-pertanyaannya.Karena penelitian tentang kemampuan berpikir spasial masih sedikit ditemukan.

\section{METODE PENELITIAN}

Metode yang digunakan dalam penelitian ini adalah kuantitatif dengan pendekatan analisis konten/isi.Analisis konten/isi merupakan teknik mengumpulkan data dengan menganalisis konten dari sebuah teks (Prasetyo dan Jannah, 2008).Sampel penelitian adalah buku teks Erlangga karangan K. Wardiyatmoko kelas XII yang pada umumnya digunakan di Kota Padang.Analisis data dilakukan dengan teknik persentase.

\section{HASIL DAN PEMBAHASAN}

\section{Pertanyaan yang Terletak di Awal Bab}

Pertanyaan yang terletak di awal bab adalah pertanyaan-pertanyaan berupa Apersepsi.Jumlah total pertanyaan yang terletak di awal bab adalah enam pertanyaan, yaitu dua pertanyaan di bab I, dan masingmasing satu pertanyaan pada bab II hingga bab V. Bab I membahas mengenai Penginderaan Jauh untuk Tata Guna Lahan dan Transportasi. Bab II membahas Pemetaan dan Sistem Informasi Geografis untuk Pembangunan.Bab III mengenai Interaksi Spasial antara Desa dan Kota. Bab IV membahas Percepatan Pertumbuhan Wilayah, dan bab V membahas Kajian Regional dan Interaksi antara Negara Berkembang dan Negara Maju.

Tabel 1. Kategori Pertanyaan Berpikir Spasial yang Terletak di Awal Bab

\begin{tabular}{lcccccccccc}
\hline \multirow{1}{*}{ Bab } & \multicolumn{2}{c}{$\begin{array}{c}\text { Non } \\
\text { spasial }\end{array}$} & \multicolumn{2}{c}{ Spasial Primitif } & \multicolumn{2}{c}{ Spasial Sederhana } & \multicolumn{2}{c}{ Kompleks } & \multicolumn{2}{c}{ Total } \\
& $\mathbf{f}$ & $\mathbf{\%}$ & $\mathbf{f}$ & $\boldsymbol{\%}$ & $\mathbf{f}$ & $\mathbf{\%}$ & $\mathbf{f}$ & $\mathbf{\%}$ & $\mathbf{f}$ & $\mathbf{\%}$ \\
\hline Bab I & 2 & $100 \%$ & 0 & 0 & 0 & 0 & 0 & 0 & 2 & $100 \%$ \\
\hline Bab II & 1 & $100 \%$ & 0 & 0 & 0 & 0 & 0 & 0 & 1 & $100 \%$ \\
\hline Bab III & 0 & 0 & 0 & 0 & 1 & $100 \%$ & 0 & 0 & 1 & $100 \%$ \\
\hline Bab IV & 1 & $100 \%$ & 0 & 0 & 0 & 0 & 0 & 0 & 1 & $100 \%$ \\
\hline Bab V & 1 & $100 \%$ & 0 & 0 & 0 & 0 & 0 & 0 & 1 & $100 \%$ \\
\hline Total & $\mathbf{5}$ & $\mathbf{8 3 , 3 3 \%}$ & $\mathbf{0}$ & $\mathbf{0}$ & $\mathbf{1}$ & $\mathbf{1 6 , 6 7 \%}$ & $\mathbf{0}$ & $\mathbf{0}$ & $\mathbf{6}$ & $\mathbf{1 0 0 \%}$ \\
\hline
\end{tabular}

Sumber: Pengolahan Data Sekunder Tahun 2018. 
Dari enam pertanyaan, lima termasuk ke dalam kategori nonspasial dengan persentase $83,33 \%$. Satu pertanyaan kategori spasial sederhana dengan persentase $16,67 \%$ dimuat pada bab III, yaitu tentang interaksi spasial antara desa dan kota. Pertanyaan yang termasuk ke dalam kategorispasialprimitif dan kompleks spasial tidak ada.

\section{Pertanyaan yang Terletak di Tengah Bab}

Pertanyaan yang terletak di tengah bab merupakan pertanyaan yang terdapat di dalam tugas-tugas yang ada di dalam teks. Jumlah total pertanyaan sebanyak 74 butir, dengan 13 pertanyaan pada bab I, 14 pertanyaan pada bab II, 24 pertanyaan pada bab III, 17 pertanyaan pada bab IV, dan 6 pertanyaan pada bab $\mathrm{V}$.

Tabel 2. Kategori Pertanyaan Berpikir Spasial yang Terletak di Tengah Bab

\begin{tabular}{|c|c|c|c|c|c|c|c|c|c|c|}
\hline \multirow{2}{*}{ Bab } & \multicolumn{2}{|c|}{$\begin{array}{c}\text { Non } \\
\text { spasial }\end{array}$} & \multicolumn{2}{|c|}{ Spasial Primitif } & \multicolumn{2}{|c|}{$\begin{array}{c}\text { Spasial } \\
\text { Sederhana }\end{array}$} & \multicolumn{2}{|c|}{ Kompleks Spasial } & \multicolumn{2}{|c|}{ Total } \\
\hline & f & $\%$ & f & $\%$ & f & $\%$ & f & $\%$ & f & $\%$ \\
\hline Bab I & 6 & $46,15 \%$ & 4 & $30,77 \%$ & 2 & $15,38 \%$ & 1 & $7,7 \%$ & 13 & $100 \%$ \\
\hline Bab II & 5 & $35,71 \%$ & 4 & $28,57 \%$ & 4 & $28,57 \%$ & 1 & $7,15 \%$ & 14 & $100 \%$ \\
\hline Bab III & 9 & $37,5 \%$ & 1 & 4,17 & 11 & $45,83 \%$ & 3 & $12,5 \%$ & 24 & $100 \%$ \\
\hline Bab IV & 8 & $47,06 \%$ & 2 & 11,76 & 5 & 29,41 & 2 & 11,77 & 17 & $100 \%$ \\
\hline Bab V & 4 & $66,66 \%$ & 1 & 16,67 & 0 & 0 & 1 & $16,67 \%$ & 6 & $100 \%$ \\
\hline Total & 32 & $43,24 \%$ & 12 & $16,22 \%$ & 22 & $29,73 \%$ & 8 & $10,81 \%$ & 74 & $100 \%$ \\
\hline
\end{tabular}

Sumber: Pengolahan Data Sekunder Tahun 2018.

Kategori nonspasial dimuat pada 32 pertanyaan dengan persentase $43,24 \%$. Sebanyak 12 pertanyaan merupakan kategori spasial primitif dengan persentase $16,22 \%$, 22 pertanyaan termasuk kategori spasial sederhana dengan persentase $29,73 \%$, dan kategori kompleks spasial sebanyak 8 pertanyaan dengan persentase $10,81 \%$. Bab yang paling banyak memuat pertanyaan kompleks spasial adalah bab III. Jika diurutkan, kategori nonspasial mendominasi pertanyaan-pertanyaan yang terletak pada tengah bab, dilanjutkan spasial sederhana, spasial primitif, dan kompleks spasial.

\section{Pertanyaan yang Terletak di Akhir Bab}

Pertanyaan yang terletak di akhir bab merupakan pertanyaan-pertanyaan yang terdapat di dalam evaluasi dan latihan ulangan setiap semester. Jumlah total pertanyaan yang terdapat dalam buku yang diolah adalah 290 butir. Pada bab I terdapat 43 pertanyaan, 38 pertanyaan pada bab II, 87 pertanyaan pada bab III, 39 pertanyaan pada bab IV, dan 83 pertanyaan pada bab V. 
Tabel 3. Kategori Pertanyaan Berpikir Spasial yang Terletak di Tengah Bab

\begin{tabular}{|c|c|c|c|c|c|c|c|c|c|c|}
\hline \multirow[t]{2}{*}{ Bab } & \multicolumn{2}{|c|}{$\begin{array}{c}\text { Non } \\
\text { spasial }\end{array}$} & \multicolumn{2}{|c|}{ Spasial Primitif } & \multicolumn{2}{|c|}{ Spasial Sederhana } & \multicolumn{2}{|c|}{ Kompleks Spasial } & \multicolumn{2}{|c|}{ Total } \\
\hline & f & $\%$ & f & $\%$ & f & $\%$ & f & $\%$ & f & $\%$ \\
\hline Bab I & 25 & $58,15 \%$ & 6 & $13,95 \%$ & 6 & $13,95 \%$ & 6 & $13,95 \%$ & 43 & $100 \%$ \\
\hline Bab II & 23 & $60,53 \%$ & 3 & $7,89 \%$ & 4 & $10,53 \%$ & 8 & $21,05 \%$ & 38 & $100 \%$ \\
\hline Bab III & 33 & $37,93 \%$ & 16 & $18,39 \%$ & 27 & $31,03 \%$ & 11 & $12,65 \%$ & 87 & $100 \%$ \\
\hline Bab IV & 31 & $79,48 \%$ & 1 & $2,56 \%$ & 4 & $10,26 \%$ & 3 & $7,70 \%$ & 39 & $100 \%$ \\
\hline Bab V & 51 & $61,45 \%$ & 18 & $21,69 \%$ & 14 & $16,86 \%$ & 0 & 0 & 83 & $100 \%$ \\
\hline Total & 163 & $56,21 \%$ & 44 & $15,17 \%$ & 55 & $18,97 \%$ & 28 & $9,65 \%$ & 290 & $100 \%$ \\
\hline
\end{tabular}

Sumber: Pengolahan Data Sekunder Tahun 2018.

Sebanyak 163 pertanyaan termasuk kategori nonspasial dengan persentase $56,21 \%$. Pertanyaan yang termasuk kategori spasial primitif sebanyak 44 dengan persentase 15,17\%, 55 pertanyaan termasuk kategori spasial sederhana dengan persentase $22,72 \%$, dan 28 pertanyaan merupakan kategori kompleks spasial dengan persentase
$9,65 \%$. Bab yang paling banyak memuat pertanyaan kompleks spasial adalah bab III, mengenai interaksi spasial antara desa dan kota.

Secara keseluruhan, dapat disimpulkan bahwa kategori nonspasial mendominasi pertanyaan yang terletak di awal, tengah, dan akhir buku.Perhatikan tabel 4.

Tabel 4.Perbandingan Persentase Kategori Pertanyaan Berpikir Spasial Menurut Jo-Bednarz di dalam Buku Teks Erlangga Kelas XII.

\begin{tabular}{|c|c|c|c|c|c|c|c|c|c|c|}
\hline \multirow[b]{2}{*}{ Bab } & \multicolumn{2}{|c|}{$\begin{array}{c}\text { Non } \\
\text { spasial }\end{array}$} & \multicolumn{2}{|c|}{ Spasial Primitif } & \multicolumn{2}{|c|}{ Spasial Sederhana } & \multicolumn{2}{|c|}{ Kompleks Spasial } & \multicolumn{2}{|c|}{ Total } \\
\hline & f & $\%$ & f & $\%$ & $\mathbf{f}$ & $\%$ & $\mathbf{f}$ & $\%$ & $\mathbf{f}$ & $\%$ \\
\hline Awal & 5 & $83,33 \%$ & 0 & 0 & 1 & $16,67 \%$ & 0 & 0 & 6 & $100 \%$ \\
\hline Tengah & 32 & $43,24 \%$ & 12 & $16,22 \%$ & 22 & $29,73 \%$ & 8 & $10,81 \%$ & 74 & $100 \%$ \\
\hline Akhir & 163 & $56,21 \%$ & 44 & $15,17 \%$ & 55 & $18,97 \%$ & 28 & $9,65 \%$ & 290 & $100 \%$ \\
\hline Jumlah & 200 & $54,05 \%$ & 56 & $15,14 \%$ & 78 & $21,08 \%$ & 36 & $9,73 \%$ & 370 & $100 \%$ \\
\hline
\end{tabular}

Sumber: Pengolahan Data Sekunder Tahun 2018.

Dari tabel 4 bisa dilihat pengkategorian pertanyaan-pertanyaan yang ada di dalam buku teks Erlangga kelas XII berdasarkan letak. Dari 370 pertanyaan, enam pertanyaan terletak di awal bab, 74 pertanyaan terletak di tengah bab, dan 290 pertanyaan terletak di akhir bab.

\section{PENUTUP}

Berdasarkan hasil penelitian yang telah dijabarkan sebelumnya, dapat disimpulkan bahwa kategori nonspasial masih mendominasi pertanyaan-pertanyaan yang terdapat di dalam buku teks geografi kelas XII.Baik pertanyaan yang terletak di awal bab, tengah bab, dan akhir bab. Kategori nonspasial termuat di dalam 200 pertanyaan dengan persentase $54,05 \%$, dengan lima pertanyaan yang terletak di awal bab, 32 terletak di tengah bab, dan 163 terletak di akhir bab. Untuk kategori spasial primitif terdapat 56 pertanyaandengan persentase $15,14 \%$. Sebanyak 12 pertanyaan di tengah bab dan 44 pertanyaan di akhir bab. Sebanyak 78 pertanyaan termasuk kategori 
spasial sederhana dengan persentase $21,08 \%$, dimana satu pertanyaan terletak di awal bab, 22 di tengah bab, dan 55 di akhir bab. Terakhir, pertanyaan yang termasuk kategori kompleks spasial sebanyak 36 butir dengan persentase 9,73\%, dimana 6 pertanyaan terletak di awal bab, 8 di tengah

\section{DAFTAR PUSTAKA}

Ahyuni. 2016. Pengembangan Bahan Ajar Berpikir Spasial Bagi Calon Guru Geografi. Padang: Fakultas Ilmu Sosial Universitas Negeri Padang. (http://repository.unp.ac.id/14084/1/ AHYUNI\%2018.pdf)

Bednarz, Sarah Witham dan Injeong Jo. 2009. Evaluating Geography Textbook Questions from a Spatial Perspective: Using Concepts of Space, Tools of Representation, and Cognitive Processes to Evaluate Spatiality. Jurnal. Texas: A\&M University.

Downs, Roger M et al. 2006. Learning to Think Spatially. Washington D.C: The National Academic Press.

Jo, Injeong. 2007. Aspects of Spatial Thinking in Geography Textbook Questions. Tesis. Texas: A\&M University.

Lutfianingsih, Irma. 2017. Studi Komparasi Kemampuan Berpikir Spasial (Spatial Thinking Ability) Antara Siswa Kelas XII IPS dan XII IPA di SMA Negeri 10 Yogyakarta. Jurnal. bab, dan 28 di akhir bab. Jadi, dapat disimpulkan bahwa buku teks Erlangga karangan Wardiyatmoko didominasi berturut-turut oleh pertanyaan kategori nonspasial, spasial sederhana, spasial primitif, dan kompleks spasial.

Sugiyono. 2014. Metode Penelitian Kombinasi (Mixed Methods). Bandung: Alfabeta.

Prasetyo, Bambang dan L.M Jannah. 2008. Metode Penelitian Kuantitatif. Jakarta: PT. RajaGrafindo Persada. 
